\title{
KHALEED ABOU EL FADL'S HERMENEUTIC: A NEWLY PROPOSED INSIGHT TO REVIEW IBN RUSHD'S THEORY OF DESPOTIC INTERPRETATION OF THE QUR'AN
}

\section{Muzayyin}

Nahdlatul Ulama Islamic Institute (IAINU) Kebumen

Email: muzayyinqori@gmail.com

\begin{abstract}
This paper examines Ibn Rushd's theory of interpretation of the Qur'an by using a new methodology of hermeneutic developed by Khaleed Abou El Fadl. He proposes a theory of 'negotiating hermeneutic', in his work Speaking in The God's Name: Islamic Law, Authority, and Womans. This theory advances the role of text (the Qur'an and hadith), authors (mufti, interpreter, special agent), and readers (Muslim society, common agent) in determining the objective of an authoritative text. These are three elements that must work together to determine meanings. Abou El Fadl's hermeneutic theory develops the idea of autonomous and open texts. Therefore, the interpretation of the text does not always focus on locating the author's desired intent. Building on El Fadl's theory, the study aims to review Ibn Rushd's authoritarian interpretation, which tends to push away any other understanding which is opposite to an interpreter's ideology. Hence, this theory is contrary to another theory which states that there are no authoritative figures who can objectively understand the Qur'an.
\end{abstract}

Keywords: Hermeneutic, Khaleed Abou El-Fadl, Ibn Rushd, Authoritarianism.

DOI: http://dx.doi.org/10.20414/ujis.v20i1.534 


\section{Introduction}

TODAY'S PHENOMENON put upon surface the truth claiming of each religious community or organisation, religious lawmaker organisation (such as Permanent Council for specific Research And Legal Opinion (CRLO), Babsul Masàil, Majlis Tarjih, Dewan Hisbah, Komisi Fatwa MUI), school of thought and movement. ${ }^{1}$ Each of them insists on claiming the absolute truth of their understanding(s) that generates their rejection to others. ${ }^{2}$ The others would be blamed as astray, godless or even infidel. ${ }^{3}$ Thus, they apply authoritarianic approach on religious text which causes high tension and problematic situation. ${ }^{4}$ They confess themselves as the representative of God and further the only one who is authoritatively able to speak in God's name. ${ }^{5}$

Such authoritarianic approach would lead them to the authoritarian interpretation of the Qur'an and would be so despotic. ${ }^{6}$ Once they interpret the Qur'an despoticly, they would wrest the objective of the divine text and usurp the authority from its author (God). ${ }^{7}$ This would make them behave exclusively and intolerantly and negate the objective of the religious law maqāsid al-shari' ${ }^{-6}$ h that may spur violence actions. ${ }^{8}$

Khaleed Abou El Fadl is concerned with this despotic interpretation and criticies this tendency. In his book, Speaking in God's Name; Islamic Law, Authority, and Women, ${ }^{9}$ he said that the

${ }^{1}$ Amin Abdullah, "Foreword" Hermeneutika al-Qur'an Tema-tema Kontroversial (Yogyakarta: eLSAQ Press, 2005), xix.

${ }^{2}$ Tholhatul Choir, Islam dalam Berbagai Pembacaan Kontemporer (Yogyakarta: Pustaka Pelajar,2009),154.

3Ibid., 154.

${ }^{4}$ Charles Kimball, When Religion Becomes Evil (New York: Harper Collins Publishers, 2008).

${ }^{5}$ Abdullah, "Forew rod", xix-xx.

"Amin Abdullah, "Foreword" Atas Nama Tuhan: dari Fikih Otoriter ke Fikih Otoritatif, translated by Khaleed Abou el-Fadl (Jakarta: Serambi Ilmu Semesta, 2004), xii.

${ }^{7}$ Abdullah, Mendengarkan, xx.

${ }^{8}$ See Kimball, When Religion,

${ }^{9}$ Historical idea on the emergence of his works, precisely as the respond to the issues of religious legal opinion which is legalized by SAS (The Society for Adherence to the Sunnah) in U.S. and CRLO (Council for Scientific Research and Legal Opinions/al-Lajnah al-Dä'imah li al-Bubüth al-Tlmiyyah wa al-Iftä') in Egypt. 
authoritarian-despotic interpretation is unappropriate and it needs to be rejected. Such interpretation only considers the literal analysis which may easily generate intolerance and irrational understanding of the Qur'an. By considering the relations between text, author and reader as important parts of understanding texts and avoiding authoritarianism, ${ }^{10} \mathrm{El} \mathrm{Fadl}$ process a theory of hermeneutic. ${ }^{11}$ This theory is then wellknown as negotiating theory.

Khaleed M. Abou El Fadl was born in 1963 in Kuwait. He is distinguished Professor of Law at the UCLA School of Law where he has taught courses on International Human Rights, Islamic jurisprudence, National Security Law, Law and Terrorism, Islam and Human Rights, Political Asylum, and Political Crimes and Legal Systems. He is also the Chair of the Islamic Studies Program at the University of California, Los Angeles. He has lectured on and taught Islamic law in the United States and Europe in academic and non-academic environments since approximately 1990. He holds a B.A. in Political Science from Yale University, a J.D. from the University of Pennsylvania Law School, and an M.A. and Ph.D. in Islamic law from Princeton University. He also has 13 years of instruction in Islamic jurisprudence, grammar and eloquence in Egypt and Kuwait. After law school, he clerked for Arizona

Khaleed Abou El Fadl argues that the legal opinion issued by both considerably problematic. The signs of this problem can be shown from the way they acquire the primary sources like Hadits as well as the use of logic in term of deciding legal opinion itself.

${ }^{10}$ Authoritarianism is empowered process to the reader in order to stop the role of the author and the text. Khaleed is saying that that is a despotic act. He further argues: if the reader attempts to lock the text into a specific meaning, this act risks violating the integrity of the author and the text. Affectively, the reader is saying "I know what the author meant, and I know what does the text said; my knowledge ought to be conclusive and final". See more detail in Khaleed M. Abou el Fadl, Speaking in God's Name: Islamic Law, Authority, and Women (Oxford: Oneworld Publications, 2001), 92.

${ }^{11}$ Hermeneutic is frame of new methodology which is originated from western tradition of biblical studies. Some scholars applied it for many years to analyze the problem of the scriptural texts (Bible Old Testament and New Testament). See Gerald L. Burris, Hermeneutic, Ancient \& Modern (New Haven: Yale University Press, 1992). 
Supreme Court Justice James Moeller and practised immigration and investment law in the U.S. and the Middle East. He previously taught Islamic law at the University of Texas School of Law at Austin, Yale Law School and Princeton University. He is also a prolific author. He wrote many books. ${ }^{12}$

El Fadl proposes five requirements in the theory of negotiating hermeneutics: bonesty, diligence, comprehensive, reasonableness and self-restraint. This article aims to use Fadl's hermeneutic to review Ibn Rushd's theory in interpreting the Quran. The latter theory is characterised by exclusivity and refusion to different interpretation. Such an understanding of the text may be termed as authoritarian-despotic interpretation, which is contrary to Fadl's theory.

\section{Khaleed Abou El Fadl's Hermeneutic Theory and Its Relevance to the Objectivist-Cum-Subjectivist}

Hermeneutic deals with the way(s) in which readers interpret text. It tries to solve the problems of understanding text, especially when readers attempt to force their dominant view on text and claim such understandings absolute. Hermeneutic then sees whether audience interprets a text objectively or subjectively. This leads a hermeneutic to cluster audience's act of reading into objectivist, subjectivist and objectivist-cumsubjectivist.

${ }^{12} \mathrm{Abou} \mathrm{El} \mathrm{Fadl} \mathrm{is} \mathrm{the} \mathrm{author} \mathrm{of} \mathrm{numerous} \mathrm{books} \mathrm{and} \mathrm{articles} \mathrm{on} \mathrm{topics}$ in Islam and Islamic law; Reasoning with God: Reclaiming Shariah in the Modern Age (Rowman \& Littlefield Publishers, Inc, Release Date: October 2014), The Search for Beauty in Islam: Conference of the Books (Rowman \& Littlefield Publishers, Inc, 2006), The Great Theft: Wrestling Islam from the Extremists (Harper San Francisco, 2005), Islam and the Challenge of Democracy (Princeton University Press, 2004), The Place of Tolerance in Islam (Beacon Press, 2002), And God Knows the Soldiers: The Authoritative and Authoritarian in Islamic Discourses (UPA/Rowman and Littlefield, 2001), Speaking in God's Name: Islamic law, Authority and Women (Onew orld Press, Oxford, 2001), Conference of the Books: The Search for Beauty in Islam (University Press of America/ Rowman and Littlefield, 2001), Rebellion and Violence in Islamic Law (Cambridge University Press, 2001), The Authoritative and Authoritarian in Islamic Discourses (Dar Taiba, 1997). 
Objectivism, as Syamsuddin names it, which is also known as hermeneutical theory, discusses the way(s) an audience could correctly understand a text. ${ }^{13}$ It strives to avoid misunderstanding of a text by observing author's objective in producing the text. It aims to reconstruct the meaning of text. ${ }^{14}$ Among the proponents of these views include Schleimacher, W. Dilthey and Emilio Betty.

The second one is philosophical hermeneutic, the opposite of the first model. According to philosophical hermeneutic, the problem is not how to understand the text correctly and objectively, but rather the "attitude of understanding" itself. The representative of this school of thought is Hiedeger, Jorge Gracia, and Gadamer. They are concerned about essence, not theory, of interpretation. Borrowing phenomenological concept of Heideger "Dassein" as its model, Gadamer then considers his hermeneutic as ontological rather than methodological. The main point of his hermeneutic is rejection to the assumption by theoretical hermeneutic that the aim of hermeneutic is to find the objective meaning of the text. Gadamer argues for the impossibility of gaining an objective understanding of the text on the basis of two reasons; the unability to replace author position and to know the original meaning of the text. He further ascertains that readers always bring their subjective prejudice in reading a text. ${ }^{15}$ Shortly, for Gadamer, the act of understanding always has to do with either horizon of exegete or borizon of text. This group represents what is known as objectivist-cum-subjectivist.

The third, hermeneutic criticism, aims to explore the interest behind text. It criticises two models mentioned before. To this group, both theoretical and philosophical hermeneutics ignore an outward aspect such as work and domination that will certainly produce the mode of thought and mode of conduct. It does not want to clarify the truth, but rather to build a subjective

${ }^{13}$ Ilham B. Saenong, Hermeneutika Pembebasan (Jakarta: Teraju, 2002), 34.

${ }^{14}$ Aksin Wijaya, Arah Baru Studi Ulum al-Qur'an (Yogyakarta: Pustaka Pelajar, 2009), 185-6.

${ }^{15}$ Hans George Gadamer, Truth and Method (New York: the Seabury Press, 1975), 264. 
assumption. On the other word, they read text with prejudice rather than to affirm. And tradition might be the place of false consciousness. ${ }^{16}$ Habermas is the best scholar representation of this group. Therefore, this group may be, according to Syamsuddin, classified as subjectivist.

Khaleed Abou El Fadl's hermeneutic seems to be influenced by Hans-George Gadamer's model of hermeneutic; his theory should be grouped as objectivist-cum-subjectivist. Specifically, Abou El Fadl's theory and methods of hermeneutics are strong. As Gadamer proclaimed, the meaning of the text is opened constantly and unlimited toward the objective of the author. ${ }^{17}$ Importantly, according to Gadamer, interpretation on the scripture is not only reproductive, but also productive. An interpreter must constantly search for new meanings, not only to reproduce them. ${ }^{18}$

\section{Khaleed Abou El Fadl's Hermeneutic Theory: Text, Author, and Reader}

The increasing of despotic interpretation and an attempt to replace the God' Sovereignty has stimulated El Fadl to respond it. He, for example, criticises the opinion of CRLO (Council for Scientific Research and Legal Opinion) that often speaks in the God's name. According to him, CRLO has created authoritarian interpretation to religious text. For instance, CRLO prohibits women's visit to grave. They have also issued a fatwa that limit women's mobility, such as the prohibition of driving automobiles and working outside. ${ }^{19}$

Fadl's hermeneutic theory is so-called "negotiating hermeneutic", because of its core which negotiate the role of the text (the Quran, hadith, and fatwa ), author (Mufti, interpreter, special agent), and reader (Moslem society, common agent) in determining the meaning of divine text. According to him, the relations of these three components should be balanced and

${ }^{16}$ Saenong, Hermeneutika Pembebasan, 42-43.

${ }^{17} \mathrm{El} \mathrm{Fadl}$, Speaking in God's Name, 146.

${ }^{18}$ Gadamer, Truth and Method, 264.

${ }^{19} \mathrm{El} \mathrm{Fadl}$, Speaking in God's Name, 272. 
must not dominate one another in determining the meaning. ${ }^{20}$ If the balance is not well maintained, it causes problems. He further argues that integrity of the text is being damaged, not dynamic, and it will loss its fluid meaning. Such a problem is called authoritarian or despotic interpretation.

In this regard, Khaleed Abou El Fadl's hermeneutics theory embraces the idea of autonomous and opened texts. Therefore, the interpretation of the text does not always focus on the efforts in finding out the author's objective. One of the main idea of El Fadl's hermeneutic is to make proportional triadic structure as the central to determine meanings of text. It aims to avoid an authoritarian or despotic interpretation. In the light of this, El Fadl tries to build the notion of conceptual frame by distinguishing authority and authoritarian. The authority has to do with the problem of authenticity of the text, and determining of meaning. Meanwhile, authoritarian closely relates to the problem regarding agent such as ruler and interpreter, those who claim themselves as the representative of God.

\section{Authenticity}

The most authoritative source to know the God's objective is the Qur'an and Sunna. According to El Fadl, both are divinely inspired sources. He argues:

The Qur'an and Sunnah are texts in the sense that they are comprised of symbol (letters and words) that invoke meaning in a reader. These texts have an author and use linguistic symbols to signify meaning. One could consider the Qur'an and Sunnah to be, in part, a set of instructions intended to address an audience. Their authoritativeness is derived from the fact that they either come from God or that they tell us something about what God is instructing us to do. ${ }^{21}$

The Next question is how we could know that the instruction truly originates from God and His prophet? To answer the question, El Fadl examines the qualification of the text. ${ }^{22}$ In regard to the qualifications, El Fadl argues:

\footnotetext{
20Ibid., 90.

21 Ibid., 86.

22Ibid.
} 
By qualifications I mean the authority of the text to speak for or about God. For instance, if a text is traced back to God [as author] or the prophet then it is eminently qualified to speak for or about the Divine. If the text goes back to a Companion speak for the Prophet, in turn, God. If the text goes back to a pious, intelligent, or knowledgeable person, we must pose the same question.we are simply asking: What competence does a particular source have to speak for or about God? This question relates to the authenticity of the medium that transmitted the authoritative instructions of the Divine. ${ }^{23}$

El Fadl notes that the Qur'an is the word of God and its authenticity is always preserved. However, he maintains that Sunnah needs "qualifications." It is important to examine the qualifications of Sunnah whether it surely represents the word of Prophet Muhammad.

\section{Determination of Meaning}

Another important thing to this issue is about the decision toward the meaning of a text. El Fadl asks 'who is entitled to decide the meaning of a text?'. In answering this question, he states that divine instructions rely on a text. They also rely on the language because it is an important tool to deliver the message. Language, however, is a tricky artefact, letters, words, phrases, and sentences that are dependent on system of symbols, and these symbols invoke particular associations, images, and emotions in an audience that may also change over time. ${ }^{24}$

In a sense, language has an objective reality because its meaning cannot be determined exclusively by the author or reader. According to $\mathrm{El} \mathrm{Fadl,} \mathrm{when} \mathrm{one} \mathrm{uses} \mathrm{the} \mathrm{medium} \mathrm{of}$ language, one is submitting to its limitations and boundaries. These boundaries are constructed in part by language users. He illustrates the interpretative image by which people interpret it. In his words "some people might think that my image is referring to the story of Adam and Eve, others might think I am referring to two people in love, others will think I am expressing boredom or that I am expressing loneliness, and crying for companionship. ${ }^{25}$

\footnotetext{
23Ibid., 86-87.

${ }^{24}$ Ibid., 89.

25Ibid., 90.
} 
It implies that text becomes pluralistic. The meaning of language is acquired through generations uses imposed limitations on its users. In a sense, once the author uses the language with all its rules and limitations, the author surrenders his or her objective(s) to the text. The author might want to express $\mathrm{X}$, but the language style he or she uses could possibly convey XY, XZ, XT or even W. The meanings of text is the best approximation of the author's intent since language itself is unconstant or unstable. ${ }^{26}$

In Islamic context, especially in the case of the Qur'an, language and the authorial objective occupy a special role. Muslims believe that the Qur'an literally is the word of God, and therefore, neither the author's intent nor the language of the text can be ignored. Muslim believes that God choose every word of the Qur'an for a reason. However, the fact remains that God choose a medium of communication that is bounded by human usage, and it develops through human dynamics. In addition, the legitimacy of a reader's determination depends on the extent to which a reader respects the integrity of the authorial intent and the text. Nevertheless, the power of determination has been delegated to the human agent. In this case, God has used two mediums: the medium of the text and the medium of the human. The text is expected to shape the attitudes and guiding the human agent, but there is little doubt that the human agent also shapes the meaning of the text. ${ }^{27}$

The question emerges does the determination of text's meaning can suitable with God's and Prophet's intent? According to El Fadl, such determination of text's meaning is an agreement among author, ${ }^{28}$ text, ${ }^{29}$ and reader, ${ }^{30}$ within negotiating

26Ibid.

27Ibid. 91.

${ }^{28 \mathrm{E} l \mathrm{Fadl}}$ argues that authors use language, most often intending to convey meaning, but cannot control the meaning actually conveyed. The language is semi-autonomous, it superimposes its own rules and limitations, and shapes and channels meaning as well. Ibid., 90.

${ }^{29}$ According to el Fadl, the text is the best approximation of the author's intent, especially since language, itself, is not constant or stable. Ibid. 
process ${ }^{31}$. It means that, searching for the meaning of text should be autonomous and open.

\section{The Authoritarian}

The last important thing other than authenticity and determination of text is authoritarianism. Avoiding the interpretative process is a despotic act. If the reader attempts to lock the text into specific meaning, then the integrity of the author and text will be violated. Effectively, the reader is saying: "I know what the author means, and I know what the text is saying; my knowledge ought to be conclusive and final". Moreover, the reader assumes that they are empowered or authorised to stop the role of the author and the text. ${ }^{32}$ Therefore, this case is related to the issue of who bears the responsibility for ascertaining and resolving the problems of competence and determination. What are the process and the institutional format for deciding authenticity, meaning and application? Is it left to the individual discretion of the followers of the religion or does it take some compulsory institutional forms? El Fadl calls this as an issue of agency. ${ }^{33}$

In the context of agency, El Fadl divides human agency into two groups; the first one is referred as special agent and the second is known as common agent. The first group has an authority to decide the meaning of text because it perceives competence to understand the principal's instructions. It is often the case that the authority is gained through social convention rather then of their formal position. ${ }^{34}$ The common agents consider the determinations of action would have some reasonable alternatives or other possibilities to discharge their obligations towards the principal. They personally have examined the textual instructions, or they have looked at non-

${ }^{30}$ Readera, according to El Fadl, have ability to impose whatever meaning he or she wishes upon the text. A reader could read this book and conclude that it is an exciting romp in the world of sensuality or that it's encoded message to the terrorists of the world. Ibid.

${ }^{31}$ Ibid.

32Ibid., 92.

33Ibid., 25-26.

34Ibid., 53. 
textual manifestations of the Divine Will such as intuition or history. However, they forget such alternatives because they think the special agents have special competence of understanding and analysing the principal's instructions. ${ }^{35}$

Such an assumption tends to raise authoritarianism in interpretation. They misuse the authority of God, by locking the text. ${ }^{36}$

\section{Scheme 1: Triadic Structure of Negotiated Hermeneutics}

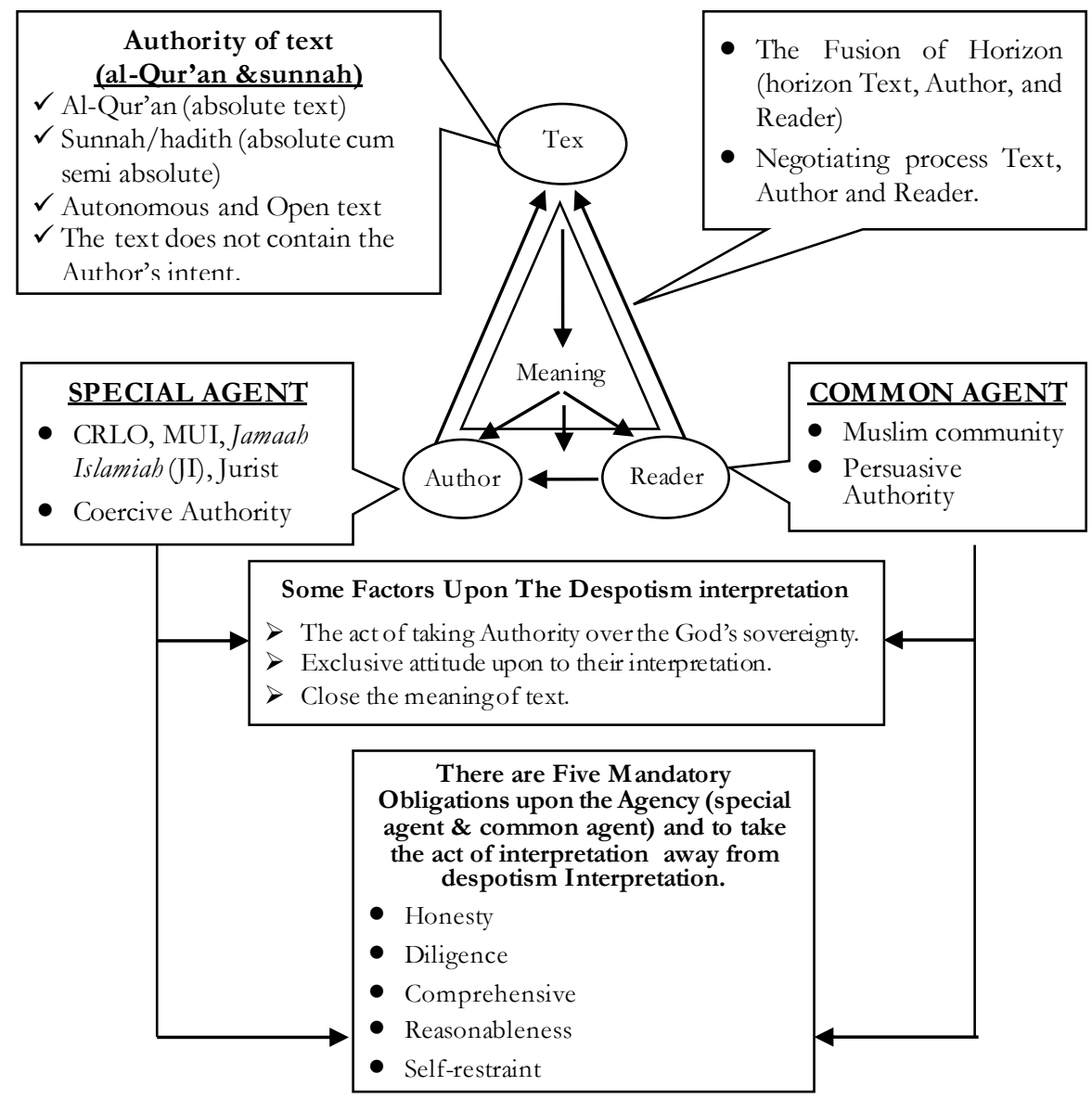

\section{Ibid., 53.}

${ }^{36} \mathrm{El} \mathrm{Fadl} \mathrm{argues} \mathrm{if} \mathrm{the} \mathrm{reader} \mathrm{attempt} \mathrm{to} \mathrm{lock} \mathrm{the} \mathrm{text} \mathrm{in} \mathrm{a} \mathrm{specific}$ meaning, this act risks violating the integrity of the author and text.effectively, the reader is saying: "I know what the author means, and I know what the text is saying; my knowledge ought to be conclusive and final." el Fadl, Speaking, 92. 


\section{Negotiated Hermeneutic as Critics to Ibn Rushd's Method of Interpretation}

El Fadl's Hermeneutic, which is explained in his books Speaking in God's Name: Islamic Law, Authority, and Women, aims to be kind of alternative approach or methodology for analyzing or responding the multiple interpretation on gender issues delivered by the Jurist such as CRLO (Council for Scientific Research and Legal Opinion). In this part, El Fadl perspective is employed to examine Ibn Rushd's thought. He is the one who is known as a Moslem philosopher who offers a perspective that harmonises shari'a and philosophy. Abū al-Wālīd Muhammad ibn Ạ̣mad ibn Rushd, better known in the Latin West as Averroes, was born in 1128 C.E. in Cordova, has been held as one of the greatest thinkers and scientists of the history. He died in Marrakesh in 1198 where he was buried. Three months later, his body was moved to Qurtuba, the tribune of his thought. Ibn Rushd's education followed a traditional path, beginning with studies in hadith, linguistics, jurisprudence and scholastic theology. He was a product of twelfth-century Islamic Spain. He set out to integrate Aristotelian philosophy with Islamic thought. A common theme throughout his writings is that there is no inappropriateness between religion and philosophy when both are properly understood. His contributions to philosophy took many forms, ranging from his detailed commentaries on Aristotle, his defence of philosophy against the attacks of those who condemned it as different to Islam and his construction of a form of Aristotelianism which cleansed it, as far as was possible at the time, of, Neoplatonic influences. His thought is genuinely creative and highly controversial, producing powerful arguments that were to puzzle his philosophical successors in the Jewish and Christian worlds. He seems to argue that there are two forms of truth, a religious form and a philosophical form and that it does not matter if they point in different directions. He also appears to be doubtful about the possibility of personal immortality or of God's being able to know that particular events have taken place. There is much in his work also which suggests that religion is inferior to philosophy as a means of attaining knowledge and that the understanding of 
religion which ordinary believers can have is very different and impoverished when compared with that available to the philosopher. In philosophy, his most important work Tahäfut alTahäfut was written in response to al-Ghazali's work. Ibn Rushd was criticised by many Muslim scholars for this book, which, nevertheless, had a deep influence on European thought, at least until the beginning of modern philosophy and experimental science. His views on fate were that man is neither in full control of his destiny nor is it fully predetermined for him. Al Rushd's longest commentary was, in fact, an original contribution as it was largely based on his analysis including interpretation of Quranic concepts. Ibn Rushd's summary the opinions (fatwa $)$ of previous Islamic jurists on a variety of issues has continued to influence Islamic scholars to the present day, notably Javed Ahmad Ghamidi. At the age of 25, Ibn Rushd also made remarkable contributions in medicine. In medicine his well-known book Kitāb al-Kulliyyah fi al-Tibb was written before 1162 A.D Its Latin translation was known as 'Colliget'. In it, Ibn Rushd has thrown light on various aspects of medicine, including the diagnoses, cure and prevention of diseases and several original observations of him. He wrote at least 67 original works, which included 28 works on philosophy, 20 on medicine, 8 on law, 5 on theology, and 4 on grammar, in addition to his commentaries on most of Aristotle's works and his commentary on Plato's The Republic. A careful examination of his works reveals that Ibn Rushd (Averroes) was a deeply Islamic man. As an example, we find in his writing, "Anyone who studies anatomy will increase his faith in the omnipotence and oneness of God the Almighty". He believed that true happiness for man can surely be achieved through mental and psychological health, and people cannot enjoy psychological health unless they follow ways that lead to happiness in the hereafter, and unless they believe in God and His oneness. ${ }^{37}$

In this part, I will use El Fadl's Hermeneutic to criticise the despotism interpretation of. There some reasons to do this sort of analysis. First, El Fadl's negotiating hermeneutic can be used

${ }^{37}$ See www.iep.utm.edu/ibnrushd/ and www.famousscientists.org/ibn-rushd/ Accessed in April 22rd, 2016. 
to comprehend the model of Rushd's theory of the interpretation of the Qur'an as examines whether Ibn Rushd construct his interpretation by gathering the text and readers. Secondly, negotiating hermeneutic is used to identify the trace of authoritarianism in Ibn Rushd's theory of interpretation. It can be used to see whether Ibn Rushd arbitrary wrest the meaning of the text exclusively and fortifies himself from performing something arbitrary or not. Third, this kind of hermeneutic also offers some strategic steps to avoid ill-treatment to a text, and blindly follow one's thought without criticism. These steps involve five moral principles to control authoritarianism, epistemological prejudice, and exclusive logic to oversee blind fanatism.

Ibn Rushd distinguishes the society into two categories: educated society and the general public. This categorization is important to classify people's ability in understanding text whether as reader, interpreter or recipient of the meaning of the Qur'an. He makes such different positions according to people's ability, character, and habits. ${ }^{38} \mathrm{He}$ classifies those in educated society as "reader" who can and even must receive ta'mil discourse of the Qur'an, while the ordinary people who only use their sensitive ability are the 'receiver' who should receive the extrinsic Qur'anic discourse.

The different point between the two, namely the educated community and the general public are also determined by the quality of the usage of methods; The first method of non-rational thinking in the form of rhetoric is intended to the general public because they rely merely on sensory satisfaction. The second, rational thinking method that consists of two methods, namely the dialectical and demonstrative, is reserved for educated people who cultivate rational thinking.

The dialectics and demonstrative method are exclusively reserved for the educated society. The question is what kind of educated people they likely are? In this regard, Ibn Rushd distinguishes educated society into two categories; philosophers

${ }^{38} \mathrm{Abū}$ al-Wālīd Muhammad ibn Aḥmad Ibn Rushd, Faṣl al-Maqal fì Mā bayna al-Hikmah wa al-Sharīah min Ittișal, Dirāsah wa Taḥqīq: Muhammad Imarah, (Cairo: Dār al-Ma'ārif, 1972), 30-31. 
and non-philosophers. ${ }^{39} \mathrm{He}$ considers them as a group who is unable to produce a convincing rational thought. He puts them in a position which is only able to generate rhetoric thought (generating satisfaction, dialectic/preservation and poetic/imagery).

Including in the category of philosophers are the Greek philosophers such as Plato and Aristotle, and the Muslim Peripatetic philosophers such as al-Fārābī and Ibn Sīnā. Ibn Rushd thought that the second group of philosophers are unworthy to represent the philosopher because they frequently use the dialectical method of kalam. 40

Ibn Rushd tries to determine the position of these groups with their respective method, particularly in understanding the Shari'a (the Qur'an). The goal is to determine the position of the subject in understanding the Shari'a, i.e. who is in the position of the reader/interpreter as well as receiver discourse of the Qur'an. He wrote:

"In conjunction with the law, people were divided into three groups: first, those who are not the experts of ta'wil (allegorical interpretation). They are rhetoricians consisting of the majority of human beings. Nobody in their right minds is excluded from being able to receive proof of this kind of rhetoric. The second group is people who are experts of ta'mil, the experts of dialectics, thanks to their talent or, additionally, their customs. Third, people who are experts of ta'mil yaqini, the experts of demonstrative, neither the skills it obtained naturally or through philosophical training. Interpretation of this group should not be distributed to a class of dialecticians, let alone the ordinary people who cultivate methods of rhetoric. For, if ta'mil was distributed to people who do not have the ability to catch it because that interpretation is above the grasp of ordinary people, meaning those who share and those who get is would be compelled to disbelief when it concerns issues of principle in the law. ${ }^{41}$

${ }^{39}$ Muḥammad 'Ābid al-Jābirī, Foreword to Al-Kashf 'an Manāhij alAdillah fi Aqāid al-Millah aw Naqd Tlmi al-Kalām Diddan 'alā al-Tarsìm alidiyulüjÿ li al-'Aqïdah wa Difä'an 'an al-Tlmi wa Khurriyyah al-Ikbtiyäri fi al-Fikri wa al-Fi li, by Ibn Rushd (Beirut: Markāz Dirāsah al-Wạ̣dah al-'Arabiyyah, 1997), 100.

40Abū al-Wālīd Muhammad ibn Aḥmad Ibn Rushd, Tahāfut al-Tahāfut (Libanon: Dār al-Fikr, 1993), 114.

${ }^{41}$ Ibn Rushd, Fasl al-Maqal, 58. 
Based on the above quotation, we can conclude that communities who are worthy to read and interpret the Qur'an are only the second and third groups. The first category may only accept the discourse of the Qur'an or some of extrinsic ta'wil discourses and should not become the interpreter, and not even worth doing the interpretation of certain verses.

Ibn Rushd criticises the dialectical method. Therefore, he does not include the dialectical argument of the groups who are experts in kalam into a rational argument because of the used methods tend to be impractical and unconvincing. He argues their method of interpretation the Qur'an is either outwardly ta'wil or allegorical one. According to him, their allegorical interpretation method does not satisfy the other two segments of society, i.e. ordinary people and philosophers.

Unlike the methods used by kaläm experts, Ibn Rushd assesses demonstrative method that was cultivated by philosophers as axiomatic method that can lead philosophers to find the truth of Shari'ah since their method is based on the notion of pure rational thinking that departs from sensory reality to the nonsensory one, God. Their method is analytical, not apologists as the dialectical method. Hence, Ibn Rushd asserts that only the philosophers (al-räsikhiun fi al-ilm) who are able to read and interpret the Qur'an. ${ }^{42} \mathrm{He}$ therefore negates the ability of others to interpret the text.

Ibn Rushd, for example, criticises, and even judges heretical, Hashawiyya movement, ${ }^{43}$ because they understand the tashbih and tajsim verses in the Qur'an on the basis of literal meanings. This movement equates what is in human to what is in God, and vice versa. They believe that God has hand and face because there are verses conveying this. ${ }^{44}$ Thus, Ibn Rushd's criticism against the Hasyawiah movement is due to their literal method to comprehend the tashbih and tajsim verses in the Qur'an. According to him, this group applies taken-for-granted meaning $(\operatorname{sim} \bar{a} \imath)$ and rejects the reasoning in the process of interpretation.

42Ibid., 38.

43al-Jābirī, al-Kashf 'an Manāhïj, 102.

${ }^{44}$ See footnote written by al-Jābirī on work of Rushd, al-Kashf 'an Manāhij, 101. 
He considers such a literal understanding deviates from the role of rationality promoted by the Qur'an. For instance, he cites Allah's words; 'O, ye people! Adore your Guardian-Lord, who created you and those who came before you, that ye may have the chance to learn righteousness, who has made the earth you couch, and the heavens you canopy; and sent down rain from the heavens; and brought forth therewith Fruits for you sustenance; then set not up rivals unto Allah when ye know (the truth). ${ }^{45}$

The school of thought adopted by Ibn Rushd's followers is demonstrative method advanced by Aristotle. Ibn Rushd advocates the demonstrative method Aristotle not only in philosophy but also in other field of Islamic science. He adored Aristotle as a man who is ma'sum (infallible). ${ }^{46}$ Even Ibn Rushd almost put him in a position as a prophet. His admiration for Aristotle's work is reflected in his words:

"This book is the work of the most rational and most noble Greeks, namely Aristotle Ibn Niqumakhis that made up the logic, physics, and metaphysics. We may say it because the previous works of science are not worth mentioning as a work in earnest. We say he is as perfect as in all the works he left to our own time, that for fifteen centuries, yet there was something else that made his work deserve the blame. The whole perfection existed in this man. It is something extraordinary because he has the excess that makes him deserve the praise his divine dimensions exceeds the humanity' dimensions of him' Aristotle al-ilabiy '(Aristotle has a dimension of divinity)." 47

The influence of Aristotle to Ibn Rushd could be seen in his use of law as a legitimate stance. Ibn Rushd declares the obligation to learn logic and philosophy, as well as classic works of Greek philosophers, especially Aristotle. ${ }^{48}$

${ }^{45}$ Qs. al-Baqarah [2]: 21-21.

${ }^{46} \mathrm{Abd}$ al-Maqsūd 'Abd al-Gānī, al-Tawfiq bayn al-Din wa al-Falsafah ind Falsafah al-Islàm fí al-Andähüs (Cairo: Maktabah al-Zahrā', 1993), 34.

${ }^{47}$ Ernes Renan, Ibn Rushd wa al-Rushdiyyah (Cairo: Dār Ihyya al-Kutub alArabiyyah, 1907), 70.

${ }^{48} \mathrm{Ibn}$ Rushd, Fașl al-Maqal, 28. 


\section{Ibn Rushd's Teory of Interpretation}

Ibn Rushd's theory of interpretation of the Qur'an aims to find objective message of God as the authority of the Shari'ah. He says:

"In this book, we want to examine outward aspects of beliefs intended by sharia to be applicable universally. We also strive to examine the intentions of shari'a makers concerning this issue because all of humankind had forced themselves to discuss this notion in Shari'ah so that heretical and diverse sects emerged. Each group claims that they are the only authoritative to take the first Sharia, while other groups with different arguments are considered heretical group, and sometimes unbelievers so that their blood and property be lawful... "49.

Such model of interpretation theory was patterned romantic-objective and aims to find an objective message of God in the Qur'an. However, hermeneutic has weakness. It can be identified from the assumption that romantic hermeneutics requires readers to objectively find the objective of the author. Within this context, romantic hermeneutics requires readers to share the same position with the author.By doing so, readers are supposed to be able to capture objectively the objective of the author.

In the perspective of philosophical hermeneutics, ${ }^{50}$ the equation of existence and experience of readers and authors as assumed by romantic hermeneutics is impossible since every single human has his or her own history so that the existence and life experiences between individuals differ from one another. This fact by itself rules out the possibility of the individual being able to equate the existence and life experiences

49al-Jābirī, al-Kashf 'an Manāhïj, 99-100.

${ }^{50}$ Gadamer might assume that it's impossible for searching the objective meaning of the author. This due to two reasons; first, one having no authority for asserting him self as the author of the text, moreover saying to know precisely the objective meaning of the text; second, the understanding is not misterius process in which the exegeter having the subjective meaning of the text. Gadamer assertes that meaning is not found in the text, but through dialogue process among community of the text, author, and reader. See Richard King, Agama, Orientalisme, dan Postkolonianisme: Sebuab Kä̈an antara Perselingkuhan Rasionalisme dan Mistisisme terj. Agung Prihartoro (Yoyakarta: Qalam, 2001), 140. 
with other individuals. The history of human life grows and changes continuously. With a history of life as it was, the individual is impossible to re-enter those of others whose own life constantly changes. ${ }^{51}$

Another reason for the existence and life experience is the achievement of an objective understanding which is also problematic because the Qur'an has been transformed into written text, namely Muṣhäf 'Uthmāni. As written text, it will experience the relative autonomy, whether it comes from the author, the reality and the first recipient. Ibn Rushd considers that the meaning of the Qur'an is deliberately set by God into physical meanings and inner one, by linking it to two categories of people; educated society and the general public. ${ }^{52}$ According to Ibn Rushd's perspective, both are placed at different positions. Educated society is positioned as the reader that can and even should receive ta'mil discourse, while the ordinary people could only receive outwardly discourse of the Qur'an. ${ }^{53}$

In this relation, Ibn Rushd asserts that it is only educated people, namely philosopher, who can read and find the meaning and the message of God objectively in the Quran, for they can exercise demonstrative method of philosophy, running on the truth. $^{54}$ This method is also referred as qiyass burbani. The demonstrative method seeks for yaqini or convince of the science that is not going to change and decay. ${ }^{55}$ Therefore, that method is a suitable media to find the knowledge essentially, and not accidentally. The essential of burbani method is to know something through causes which gave birth to the thing itself that might not be something that is no other than through reason.

Thus, the method of demonstrative (Burbāni) is a qiyas yaqini which generate the knowledge about things as they are, through reasoning with something that exists, if the cause itself includes

${ }^{51} \mathrm{Aksin}$ Wijaya, Teori Interpretasi al-Qur'an Ibn Rushd: Kritik IdeologisHermeneutis (Yogyakarta: LKiS, 2009), 300-301.

52Ibid., 301.

53Ibid., 205.

54Ibn Rushd, Fasl al-Maqal, 38.

55Ibn Rushd, Talkhis Kitab al-Burhāni, 43. 
things that can be known naturally. ${ }^{56}$ The truth that found through demonstrative qiyass is assured. ${ }^{57}$ Therefore, the choice of the model of qiyas is considered can deliver one find the message of God completely and convincingly. Then, it becomes the principle of his philosophy; 'Reasoning about things in accordance with the demands of demonstrative methods. ${ }^{58}$ Meanwhile, he thought qiyas assess the methods used by other thinkers as a method of thinking qiyass rhetoric and dialectic, which methodologically not achieves the degree of perfect and convincing. ${ }^{59}$

The removal action and giving labels misguided by Ibn Rushd against his opponent can be observed from two things: firstly, the mechanism theory of interpretation of the Qur'an which is offered by Ibn Rushd; and secondly, some examples that established by applying the theory of interpretation or the discourse of the Qur'an.

That attitude is certainly different from the will of God. God wants all people making earnest efforts in the search for His will and message through ijtiha ad. As noted by jurists, 'if mujtahid is incorrect then he will get one reward, and if mujtahid is correct then he will receive two rewards. The principle of openness is a witness to the Qur'an and tolerance to God. According to El Fadl ijtihäd is a kind of negation of the authoritarian attitude and it provides the freedom for everyone to creatively seek God's will and message in relative terms.

The Qur'an can be classified as an open text, not static or passive. It always negotiates process with the initiators and the reader in context. Additionally, the text experiences the relative autonomy and has its own objective reality that is beyond the control of the initiators or reader. The Qur'anic text provides open opportunities toward a meaning which is allowed to be contextual. Therefore, it is impossible to find out the objective message of God in the Qur'an. No one can claim as a selected reader to look for the objective message of God, and especially

\footnotetext{
56Ibid., 38.

57Ibid., 34.

58Ibn Rushd, Tahāfut al-Tahäfut, 101.

${ }^{59} \mathrm{Ibn}$ Rushd, al-Kashf al-Manähï, 102.
} 
prevents others to read the Qur'an in accordance with their needs. Anyone can read the Qur'an as long as he has the ability to be accountable for it. ${ }^{60}$

\section{Conclusion}

Ibn Rushd's theory of interpretation is called as romanticobjective and aims to find an objective message of God in the Qur'an. It can be identified from the assumption that romantic hermeneutics requires readers to objectively find the objective of the author. At that time, it is assumed the reader is able to capture objectively the objective messages of the author.

The interpretation model of the Qur'an established by Ibn Rushd illustrates how he locked the text and the authority of God, and the community to get rid another interpretation. This authoritarian attitude is certainly different from the will of God, in which people encourage to make efforts in the search for his will and message, not to end His message in term of finding the true meaning of the text. Within this context, God provides the freedom for everyone to creatively seek God's will and message in relative terms. Based on the context of negotiation process toward the Ibn Rushd interpretation, I think that Ibn Rushd did not conduct the negotiation process among the text, and the religious community as well as community of interpreter in term of interpreting the religious text. He also ignored one of five moral principles as mandatory obligations upon the agency (special agent \& common agent) such as; Honesty, Diligence, Comprehensive, Reasonableness and Self-restraint. This evidence proves that Ibn Rushd tried to interpret the Qur'an based on his own ideologies.

\section{References}

'Abd al-Gānī, 'Abd al-Maqsūd. al-Tanfiq bayn al-Din wa al-Falsafah 'ind Falsafah al-Islām fì al-Andālūs. Cairo: Maktabah al-Zahrā', 1993.

${ }^{60}$ Wijaya, Teori Interpretasi, 302-303. 
Abdullah, Amin. Foreword to the Hermeneutika al-Qur'an Tematema Kontroversial, by Fahruddin Faiz, iv-ix.Yogyakarta: eLSAQ Press, 2005.

. Foreword to Atas Nama Tuhan: dari Fikih

Otoriter ke Fikih Otoritatif, by Khaleed Abou El-Fadl, vii-xiii.

Cet.I, terj. Jakarta: Serambi Ilmu Semesta, 2004.

Choir, Tholhatul. Islam dalam Berbagai Pembacaan Kontemporer. Yogyakarta: Pustaka Pelajar, 2009.

Ernes, Renan. Ibn Rushd wa al-Rushdiyyah. Cairo: Dār Ihya alKutub al-Arabiyyah, 1907.

El Fadl, Khaleed M. Abou. Speaking in God's Name: Islamic Law, Authority, and Women. Oxford: Oneworld Publications, 2001.

Gadamer, Hans George. Truth and Method. New York: the Seabury Press, 1975.

Ibn Rushd, Abū al-Wālīd Mụ̣ammad ibn Ạ̣mad. Faṣl al-Maqal fì Mà bayna al-Hikmah wa al-Sharīah min Ittisal, Dirāsah wa Tahqīq: Muhammad 'Imarah. Cairo: Dār al-Ma'ārif, 1972. . Tahāfut al-Tahäfut. Libanon: Dār al-Fikr, 1993.

al-Jābirī, Muḥammad 'Ābid. Foreword to Al-Kashf 'an Manāhij alAdillah fì Aqā'id al-Millah aw Naqd 'Tlmi al-Kalām Diddan 'alā al-Tarsim al-idiyulüjiy li al-'Aqidah wa Difä'an 'an al-Tlmi wa Khurriyyah al-Ikhtiyäri fi al-Fikeri wa al-Fi'li, by Ibn Rushd. Beirut, Markāz Dirāsah al-Waḥdah al-'Arabiyyah, 1997.

Junaidy, Abdul Basit dan Abid Rohmanu. Islam Dalam Berbagai Pembacaan Kontemporer. Yogyakarta: Pustaka Pelajar, 2009.

Kimball, Charles.When Religion Becomes Evil. New York: Harper Collins Publishers, 2008.

King, Richard. Agama, Orientalisme, dan Postkolonianisme: Sebuah Kajian Antara Perselingkuban Rasionalisme dan Mistisisme. terj., Agung Prihartoro. Yoyakarta: Qalam, 2001.

L. Burris, Gerald. Hermeneutic: Ancient \& Modern. New Haven: Yale University Press, 1992.

Saenong, Ilham B. Hermeneutika Pembebasan. Jakarta: TERAJU, 2002.

Wijaya, Aksin. Arah Baru Studi Ulum al-Qur'an. Yogyakarta: Pustaka Pelajar, 2009.

.Teori Interpretasi al-Qur'an Ibn Rushd: Kritik Ideologisbermeneutis. Yogyakarta: LKiS, 2009. 